\title{
EGGSHELL FRAGMENTS FROM OLD NESTS AS A POSSIBLE SOURCE OF CALCIUM FOR NESTING SONGBIRDS
}

Spencer G. Sealy

Department of Biological Sciences

University of Manitoba

Winnipeg, MB R3T 2N2

Spencer.Sealy@umanitoba.ca

Poultry scientists have long known that calcium is important to the egg-laying chicken. ${ }^{1,2}$ Calcium is now recognized as being no less important to wild birds during the breeding season, with the production of eggs, including their calcareous shells, placing a drain on a bird's calcium reserves. ${ }^{3}$ Many authors have interpreted observations of wild birds ingesting calcium-rich substances or feeding them to their young as being related to their need to augment and replenish this nutrient during the reproductive season. Sources of calcium for songbirds are varied, through ingestion of calcareous (limestone) grit ${ }^{4}$, sand and gravel containing calcium salts ${ }^{5,6}$, mollusc shells ${ }^{7}$, and fragments of bone ${ }^{8}$, the latter sometimes obtained from dried feces of predatory mammals ${ }^{9,10}$ Thus, adequate nourishment of eggproducing females and their young promotes successful reproduction and increases lifetime fitness. ${ }^{11}$ An additional source of calcium for birds may be fragments of egg shell extracted from the bottom of nests that persisted over winter.

During studies (1970s through mid-1980s) of the diet of songbirds breeding in the dune-ridge forest that separates Lake Manitoba and Delta Marsh $\left(50^{\circ} 11 \mathrm{~N}, 98^{\circ} 19 \mathrm{~W}\right)^{12}$, we occasionally dissected tiny pieces of egg shell from the muscular stomachs of birds during, but not restricted to, the egg-laying period. This was not

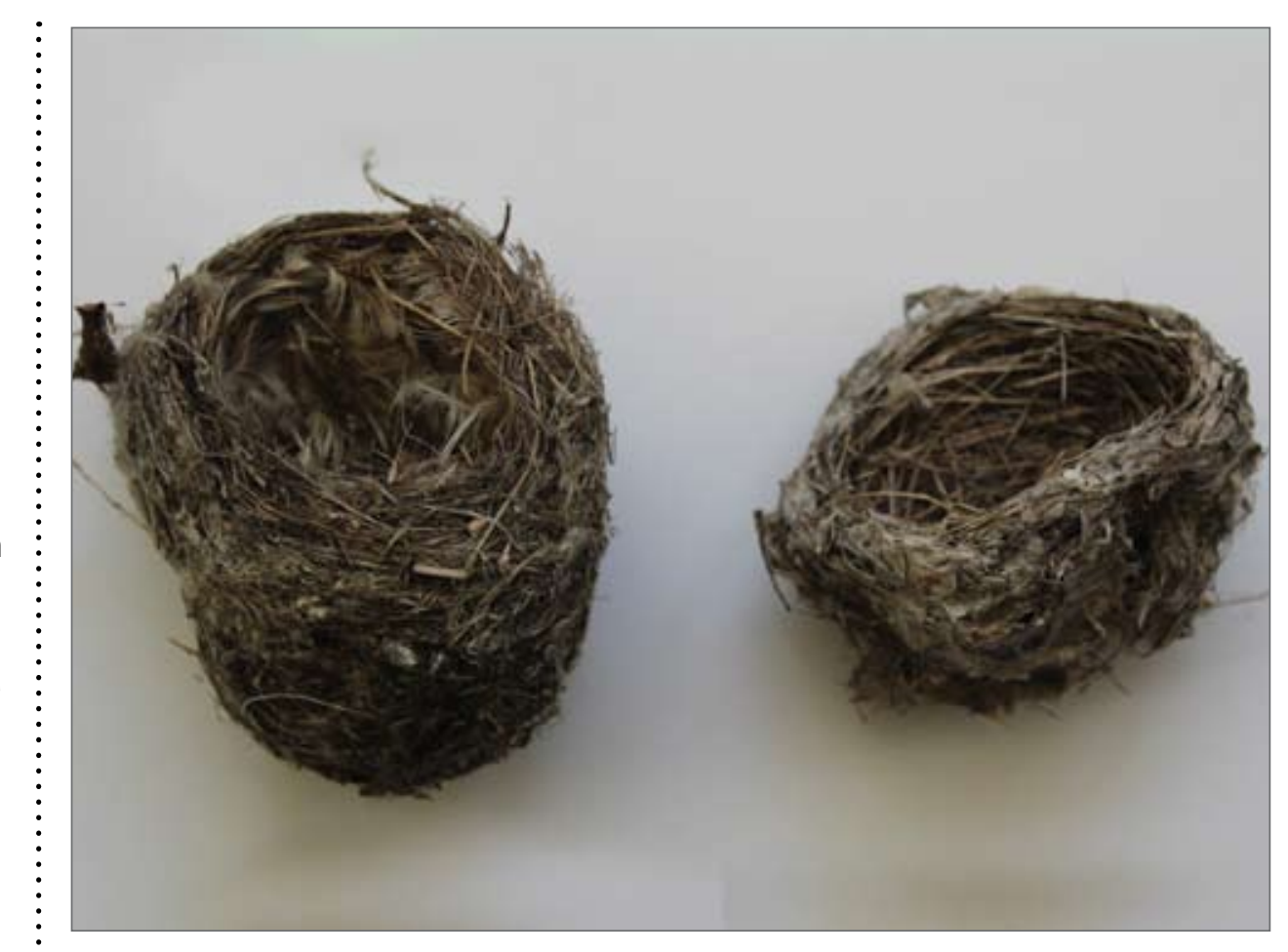

FIGURE 1. Yellow Warbler nests such as those shown above that have overwintered may provide a source of egg shell for breeding birds the following spring. The larger nest on the left contains a broken Brown-headed Cowbird egg buried in the bottom of the nest, which is another source of egg shell.

surprising, as egg shell may provide breeding birds with a source of calcium. What was not immediately known, however, was where the birds obtained pieces of egg shell during the early part of the breeding season. The likelihood that egg shells would be found on the ground amid leaf litter in spring prior to egg laying seemed remote, although most species occasionally gathered nesting material on the ground and foraged there. ${ }^{13} \mathrm{~A}$ clue to the source of egg shell emerged when I observed female Yellow Warblers (Setophaga petechia) visiting nests of their own species that persisted through the winter intact. Females frequently removed material from old nests of their own and other species to construct new ones, whereas some females pecked objects hidden from my view in the bottom of the nest, then left without nesting material. Inspection of the lining of previous years' nests from which young had fledged, now shrivelled after overwintering (Figure 1), often revealed tiny pieces of egg shell embedded in the bottom of the nest. When eggs pip and hatch, pieces of shell may fall to the bottom of the nest where they become available for ingestion later in the year or the following year. Passerine birds generally eat the shells of their eggs as they hatch, which may augment their calcium reserves or they carry and drop the shells some distance from the nest. ${ }^{14}$

We did not routinely note pieces of egg shell in stomach contents examined in studies of the diet of species breeding in the ridge 
TABLE 1. Egg shell, snail shell, and grit dissected from stomachs of Yellow Warblers at Delta Marsh, Manitoba, 1975 and 1976 (D.G. Busby, in litt., February 23, 1983). Each stomach also contained an array of insect remains.

\begin{tabular}{|c|c|c|c|}
\hline SPECIMEN NUMBER & $\begin{array}{l}\text { NO. PIECES } \\
\text { OF EGG SHELL }\end{array}$ & $\begin{array}{l}\text { NO. PIECES } \\
\text { OF SNAIL SHELL }\end{array}$ & $\begin{array}{l}\text { NO. PARTICLES } \\
\text { OF GRIT }\end{array}$ \\
\hline 75-7, 7 Jun, 우 & 0 & 1 & 0 \\
\hline 75-10, 12 Jun, 우 & 15 & 0 & 3 \\
\hline 75-13, 12 Jun, 우 & 0 & 1 & 3 \\
\hline 75-21, 29 Jun, 우 & 1 & 0 & 3 \\
\hline 75-24, 1 Jul, 우 & 4 & 0 & 0 \\
\hline 76-1, 22 May, & 1 & 0 & 0 \\
\hline 76-51, 12 Aug, HY & 3 & 0 & 5 \\
\hline
\end{tabular}

forest, with the exception of the Yellow Warbler, in 1975 and 1976 (Table 1). In this study 15 , egg and gastropod (snail) shell, and grit, were recorded infrequently in Yellow Warbler stomachs (D.G. Busby, in litt., February 23, 1983). Out of 54 stomachs $(25$ ô $\widehat{0}, 20$ 우우, 7 hatch year [HY]) examined in 1975, and 53 in 1976 (20 ठㅊ, 20 우우, 13 $\mathrm{HY})$, pieces of egg shell 1-2 $\mathrm{mm}$ in diameter were recorded in three stomachs (all o) in 1975 (5.6\%) and two stomachs ( $\widehat{\sigma}, \mathrm{HY}$ ) in 1976 (3.8\%). Snail shell was recorded in two stomachs (both o) in 1975 (3.7\%), whereas grit was noted in three stomachs (all Q) in 1975 (5.7\%) and 1 stomach (HY) in 1976 (1.9\%). These and the other Yellow Warbler stomachs examined contained mostly insects, predominately midges (Diptera: Chironomidae). ${ }^{15}$

Comparison of dates egg- and mollusc-shell ingestion were recorded (Table 1) and of clutch-initiation by Yellow Warblers in 1975 and $1976^{16}$ revealed shell was present in stomachs of adult females on dates that covered most of the egg-laying period, whereas the male ingested egg shell soon after arrival in spring, at least four days prior to the first egg laid in the population, in $1976 .{ }^{16}$ The HY individual apparently ingested egg shell and grit after the laying period in 1976 (Table 1), although the fledgling may have been fed those materials while still a nestling.

\section{Discussion}

Egg shell, snail shell, and grit were ingested purposefully by predominantly female Yellow Warblers, rather than taken accidentally with other food items. The primary methods used by Yellow Warblers to capture prey at Delta Marsh - gleaning insects from foliage or hawking them in flight ${ }^{15}$ — do not afford opportunities to obtain egg shell or grit, accidentally or otherwise. Snail shell and grit were probably obtained on the floor of the ridge forest, or possibly on the nearby shore of Lake Manitoba. Tiny pieces of egg shell probably were obtained from old nests prior to or early in the egg-laying stage, but detection of ingested egg shell likely would be underestimated because it does not preserve well in the stomach's acid environment and is rapidly broken down. ${ }^{17,18} \mathrm{In}$ addition to pieces of warbler egg shell in old nests, Brown-headed Cowbird (Molothrus ater) eggs that may have been buried in the bottom of them ${ }^{19}$ would provide another source of calcium, although it is not known with certainty whether Yellow Warblers are capable of puncturing the disproportionately thick shells of cowbirds' eggs ${ }^{20,21}$, although birds with larger and stronger beaks can puncture them 22,23

In summary, data presented here confirm that a small percentage of breeding Yellow Warblers ingested pieces of egg shell. Anecdotal observations of individuals probing apparently for shell in the bottom of old nests, then leaving without removing nesting material, however, only suggest but do not confirm that these individuals had ingested pieces of egg shell. Video recordings of this behaviour would be required, with cameras set up at old nests in situ in which the investigator has placed a known number of pieces of egg shell, from unhatched eggs or nests depredated in a previous year, in the bottom of nests. Video-taping may also reveal other species removing nest material from old Yellow Warbler nests, and possibly also pieces of egg shell.

\section{Acknowledgements}

D.G. Busby extracted the data used in Table 1 from original specimen sheets. Research at Delta Marsh in the early years was funded chiefly by the Natural Sciences and Engineering Research Council of Canada, and the Research Grants Program (University of Manitoba), augmented by in-kind support provided by the Delta Marsh Field Station (University of Manitoba). T.J. Underwood commented on a draft of the manuscript.

1. Romanoff AL, Romanoff AJ (1949) The avian egg. Wiley, New York, NY.

2. Simkiss K (1961) Calcium metabolism and avian reproduction. Biological Reviews 36:321-367.

3. Ricklefs RE (1974) Energetics of reproduction in birds. Pages 152-297 in Avian energetics (Paynter Jr, RA, editor). Publications of the Nuttall Ornithological Club, No. 15.

4. Jones PJ (1976) The utilization of calcareous grit by laying Quelea quelea. Ibis 118:575-576.

5. Verbeek NAM (1971) Hummingbirds feeding on sand. Condor 73:112-113.

6. March GL, Sadleir RMFS (1975) Studies on the Band-tailed Pigeon (Columba fasciata) 


\section{POETRY}

\section{Bandit Bird}

White-breasted nuthatch

on foray

slips headfirst down tree

on quick survey,

peers around trunk,

then, come what may,

he flits to feeder

and grabs the prey.

Beak filled with loot,

he pays no heed

to me and my camera,

watching him feed.

In sharp color photo

I've caught his deed -

black-hooded thief

with a sunflower seed.

\section{Donna Gamache}

Box 453

MacGregor, MB ROH ORO

(204) 685-2574

lucgam@mymts.net

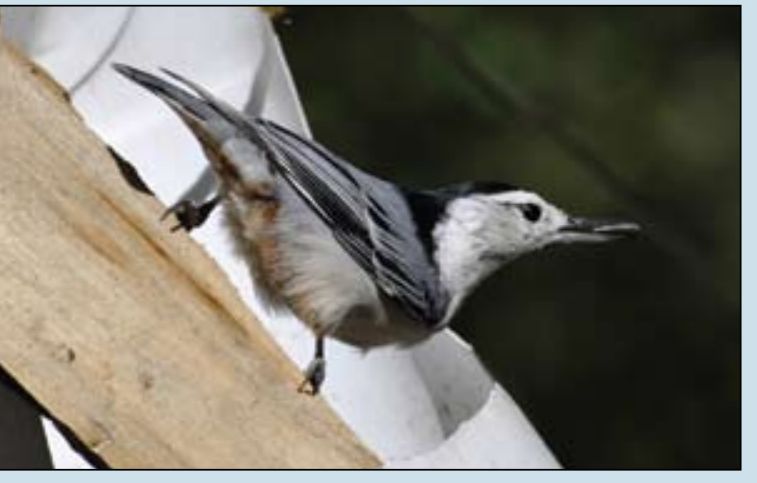

Nuthatch bandit. Photo credit: Donna Gamache in British Columbia. III. Seasonal changes in body weight and calcium distribution. Physiological Zoology 48:49-56

7. Ankney CD, Scott DM (1980) Changes in nutrient reserves and diet of breeding Brown-headed Cowbirds. Auk 97:684-696

8. MacLean SF (1974) Lemming bones as a source of calcium for Arctic sandpipers (Calidris spp.). Ibis 116:552-557.

9. Payne RB (1972) Nuts, bones, and a nesting of Red Crossbills in the Panamint Mountains, California. Condor 74:485-486.

10. Staniforth R, Koes R (2012) An observation of ground feeding and coprophagy by a Common Nighthawk in NW Manitoba. Blue Jay 71:132-134

11. Lack D (1968) Ecological adaptations for breeding in birds. Methuen, London, UK.

12. MacKenzie DI (1982) The dune-ridge forest, Delta Marsh, Manitoba: Overstory vegetation and soil patterns. Canadian FieldNaturalist 96:61-68.

13. Pohajdak GC (1988) Feeding guilds, diets, and foraging behavior of insectivorous passerines in a riparian habitat in Manitoba. Ph.D. dissertation, University of Manitoba, Winnipeg.

14. Guigueno MF, Sealy SG (2012) Nest sanitation in passerine birds: Implications for egg rejection in hosts of brood parasites. Journal of Ornithology 153:35-52.

15. Busby DG, Sealy SG (1979) Feeding ecology of a population of nesting Yellow Warblers. Canadian Journal of Zoology 57:1670-1681

16. Goossen JP, Sealy SG (1982) Production of young in a dense nesting population of Yellow Warblers, Dendroica petechia, in Manitoba. Canadian Field-Naturalist 96:189199

17. Duffy DC, Jackson S (1986) Diet studies of seabirds: A review of methods. Colonial Waterbirds 9:1-17.

18. Bureš S, Weidinger K (2003) Sources and timing of calcium intake during reproduction in flycatchers. Oecologia 442:634-647.

19. Sealy SG (1995) Burial of cowbird eggs by parasitized Yellow Warblers: An empirical and experimental study. Animal Behaviour 49:877-889
20. Spaw CD, Rohwer S (1987) A comparative study of eggshell thickness in cowbirds and other passerines. Condor 89:307-318.

21. Guigueno MF, Sealy SG (2010) Clutch abandonment by parasitized Yellow Warblers: Egg burial or nest desertion? Condor 112:399-406

22. Sealy SG (1996) Evolution of host defenses against brood parasitism: Implications of puncture-ejection by a small host. Auk 113:346-355.

23. Sealy SG, Neudorf DL (1995) Male Northern Orioles eject cowbird eggs: Implications for the evolution of rejection behavior. Condor 97:369-375.

\section{Editor's Correction for Volume 75.2 Leopard Frog predation on emerging adults of colonizing variegated meadowhawk dragonflies.}

Blue Jay has a wide audience of scientific and lay persons. To facilitate communication and make sure that everyone is referring to the same animal, standard common and scientific names are used. The North American standard for amphibian and reptile names is: Scientific and Standard English Names of Amphibians and Reptiles of North America North of Mexico, with Comments Regarding Confidence in Our Understanding, 7th Edition (2012, SSAR Herpetological Circular No. 39).

Using this standard, the names of amphibians noted in this paper change as follows: the scientific name for Northern Leopard Frog is Lithobates pipiens; the frogs referred to as Striped Chorus Frogs are probably Boreal Chorus Frogs, Pseudacris maculate; the scientific name for the tiger salamanders mentioned in the paper is Ambystoma mavortium. 